\title{
Labyrinthe
}

15 | 2003

Territoires : questions d'images

\section{Enfances africaines en France : des socialisations plurielles}

Sophie Maurer

\section{(2) OpenEdition \\ 12 Journals}

Édition électronique

URL : http://journals.openedition.org/labyrinthe/479

DOI : $10.4000 /$ labyrinthe.479

ISSN : 1950-6031

Éditeur

Hermann

Édition imprimée

Date de publication : 1 juin 2003

Pagination : 81-96

Référence électronique

Sophie Maurer, «Enfances africaines en France : des socialisations plurielles », Labyrinthe [En ligne],

15 | 2003, mis en ligne le 24 mars 2005, consulté le 06 mai 2019. URL : http://

journals.openedition.org/labyrinthe/479; DOI : 10.4000/labyrinthe.479

Ce document a été généré automatiquement le 6 mai 2019.

Propriété intellectuelle 
Enfances africaines en France : des socialisations plurielles

\author{
Sophie Maurer
}

